\title{
Antioxidant activity of essential oil from Coriandrum Sativum L. in Italian salami
}

\author{
Atividade antioxidante do óleo essencial de Coriandrum sativum L. em salame italiano
}

\author{
Cristiane MARANGONI ${ }^{1 *}$, Neusa Fernandes de MOURA ${ }^{1}$
}

\begin{abstract}
Four formulations of Italian salami type were produced: without antioxidants; with essential oil of coriander essential oil (0.01\%); with BHT (0.01\%); and with Coriander essential oil and BHT (0.005 and $0.005 \%)$. The antioxidant activity of salamis was evaluated by the lipid oxidation, through the techniques of peroxide number and TBARS. The salami with the coriander essential oil exhibited reduction in lipid oxidation by increasing the shelf life of the product. The salami with the coriander essential oil and BHT showed no synergism between the antioxidants. The salami using BHT presented less antioxidant activity than that of the salami using coriander essential oil.

Keywords: Coriandrum sativum L.; antioxidant; TBARS; Italian salami; lipid oxidation.
\end{abstract}

\section{Resumo}

Quatro formulações de salame tipo italiano foram produzidas: sem antioxidantes, com óleo essencial de coentro $(0,01 \%)$, com BHT $(0,01 \%)$ e outro com óleo essencial de coentro e BHT (0,005 e 0,005\%). A atividade antioxidante dos salames foi avaliada pela oxidação lipídica, através das técnicas de índice de peróxidos e TBARS. O salame com o óleo essencial de coentro mostrou redução da oxidação lipidica e indicou aumento da vida útil do produto. O salame com óleo essencial de coentro e BHT, não mostrou sinergismo entre os antioxidantes. O salame utilizando BHT demonstrou menor atividade antioxidante que o salame utilizando óleo essencial de coentro.

Palavras-chave: coentro; antioxidante; TBARS; salame italiano; oxidação lipídica.

\section{Introduction}

Lipid oxidation is a main deteriorative reaction that occurs during processing, distribution, storage, and final preparation of foods. These oxidative reactions result in the destruction of fat soluble vitamins and essential fatty acids, as well as undesirable changes in color, flavor, aroma, and consistency of the food, making them unfit for consumption (GRAY; GOMMA; BUCKLEY, 1996; LUZIA; JORGE, 2009).

In the food industry, lipid oxidation is inhibited by synthetic antioxidants such as Butyl hydroxyanisol (BHA), Butyl hydroxytoluene (BHT), Terc butyl hidroxiquinona (TBHQ), and Propil gallate (PG). The use of those compounds has been questioned in many studies in terms of their safety due to risks of causing heart diseases and carcinogenesis. For this reason, in the European continent and other countries such as Japan, Canada, and the United States, the use of certain synthetic antioxidants in foods is not permitted. In other countries, such as Brazil, there are limits to the use of synthetic antioxidants in foods (MARIUTTI; BRAGAGNOLO, 2007; GALVÃO et al., 2008; TAKEMOTO; TEIXEIRA FILHO; GODOY, 2009).

The oxidation of meat lipids is a complex process, and its dynamics depends on numerous factors, including chemical composition of the meat, light, and oxygen access, as well as storage temperature (SILVA; BORGES; FERREIRA, 1999). Lipid oxidation causes the degradation of polyunsaturated fatty acids and the generation of numerous other compounds which have and adverse effect on organoleptic qualities (QUAST; AQUINO, 2004). This process frequently limits the shelf-life of processed meat.

Food lipids oxidation is considered to be a risk factor for human health. Some lipid oxidation can also have a negative effect on nutritional value, and may be responsible for the production of toxic compounds capable of triggering metabolic disorders such as mutagenesis, carcinogenesis, circulatory disorders, and ageing (GUARDIOLA et al., 1996; MARIUTTI; BRAGAGNOLO, 2007).

One method to reduce lipid oxidation is the application of antioxidants. The antioxidants commonly used in food products today are butyl hydroxyanisol (BHA) and butyl hydroxytoluene (BHT). In recent years, the safety of synthetic food additives, including the possible toxicity of these chemicals used as antioxidants, has received increasing attention (KAHL; KAPPUS, 1993; ESTEVEZ et al., 2007). So, there is need for other components to act as antioxidants and to render food products safer for making. Those antioxidants include extracts obtained from plants, especially coriander (Coriandrum sativum L.) (WANGENSTEEN; SAMUELSEN; MALTERUD, 2004). The compounds present in this species, have been reported to inhibit the growth of a range of microorganisms (DELAQUIS et al., 2002), and inhibition of lipid peroxidation is reported as well

Recebido para publicação em 25/1/2009

Aceito para publicação em 1/11/2009 (004039)

Ciências Ambientais, Universidade Comunitária Regional de Chapecó - UNOCHAPECÓ, Av. Senador Attílio Fontana, 591, CEP 89809-000, Chapecó - SC, Brasil, E-mail: eng.cristiane@gmail.com

${ }^{*}$ A quem a correspondência deve ser enviada 
(ANILAKUMAR; NAGARAJ; SANTHANAM, 2001; TANABE; YOSHIDA; TOMITA, 2002; HASHIM et al., 2005).

The determination of the antioxidant activity of natural products began with Chipault et al. (1952) in spices, ingredients used in food since the early days of history, not only to enhance or highlight the organoleptic characteristics of food, but also to preserve them. Chipault et al. (1952) showed antioxidant effect in 32 spices, in which sage and rosemary were considered the most effective. Subsequently, this action has been proven in oregano and thyme (KIKUZAKI; NAKATANI, 1989; VEKIARI et al., 1993; ROTA et al., 2008) in ginger (KIKUZAKI; NAKATANI, 1989), in pepper (LEE; HOWARD; VILLALÓN, 1995), in mustard (AMAROWICZ et al., 1996), cinnamon (MANCINI FILHO et al., 1998), and coriander (SEMWAL; ARYA, 1992; ÖZCAN; AKGÜL, 1995). In most cases, the antioxidant activity of these plants is directly related to the levels of naturally occurring phenolic compounds, confirming the importance of lipid oxidation stability

The main objective of this study was the use of a natural ingredient, coriander essential oil and verify their antioxidant activity in order to delay the lipid oxidation of Italian salami and compare this effect with that displayed by a synthetic antioxidant (BHT).

\section{Materials and methods}

\subsection{Extraction of the essential oil}

Samples of coriander (Coriandrum sativum L.) were purchased at a farmer's market in Chapecó - SC and Colombo PR, between the months of June and August 2006. The aerial part of the plant was dried at room temperature and finely ground $(0.5 \mathrm{~mm})$. The ground coriander was subjected to steam distillation for 4 hours using a Clevenger apparatus to produce the essential oil. After extraction, the essential oil was separated from from water using ethyl ether and was dried with anhydrous sodium sulfate.

A yellowish oil was obtained, which was stored in a refrigerator $\left(8^{\circ} \mathrm{C}\right)$ until use. For each $100 \mathrm{~g}$ of the dried ground coriander, $1.2 \mathrm{~g}$ of essential oil were obtained.

\subsection{Manufacturing of Italian salami}

All salamis were manufactured using the same technology, ingredients and formulation, which were: a) raw material (\% w/w): beef (20), pork (60), and fat (17); b) additives and other ingredients (\%): $\mathrm{NaCl}$ ( 1.5), glicose (0.9), sodium nitrate (0.008), sodium nitrite (0.007), and condiments (0.56); and c) a microbial starter (\%): starter culture Combi ${ }^{\oplus}(0.025)$. Meat and back fat were processed in a mincer equipped with an adjustable plate set at a hole diameter of $12 \mathrm{~nm}$. Next, they were inoculated with the starter culture. The four treatments were: without antioxidant (T1), coriander essential oil $(0.01 \%)$ (T2), BHT $(0.01 \%)$ (T3), and coriander essential oil $(0.005 \%)$ and BHT $(0.005 \%)(\mathrm{T} 4)$. The final mixes were stuffed into synthetic casings ( $70 \mathrm{~mm}$ diameter). The salamis were smoked for 24 hours at the temperatures ranges from 28 to $36^{\circ} \mathrm{C}$. Next, the salamis were cured for 35 days at room temperature of 16 to $18^{\circ} \mathrm{C}$ and relative humidity of $70 \%$. After curing, the salamis were vacuum packed and kept at temperatures below $22^{\circ} \mathrm{C}$.

\subsection{Chemical analysis}

Protein (Kjedhal nitrogen), moisture (over air-drying method), fat (sohxlet), and acidity were analyzed following the AOAC (ASSOCIATION..., 1995) procedures. Water activity (Aw) was determined using an AQUALAB 3TE equipment and the $\mathrm{pH}$ using Digimed (DM-20). Sodium nitrite was determined by the method developed by Araújo and Mídio (1989) in a spectrophotometer at a wavelength of $538 \mathrm{~nm}$. During storage, lipid oxidative changes in the salamis were periodically assessed by the determination of peroxide and TBARS values. Analyses of peroxide number and TBARS data were performed weekly during the first 42 days, at 60 , and 90 days of the salami shelf life tracking.

The assessment of peroxide value was carried out based on the standard in fat extract from meat products standard according to Lanara (BRASIL, 1981) with the use of chloroform solvent, and the results are expressed as (mEq. $\left.\mathrm{g}^{-1}\right)$. On the other hand, the TBARS (2-ThioBarbituric Acid Reactive Substances) values were determined using TBARS, ThioBarbituric Acid Reactive Substances were determined using the method developed by Tarladgis, Pearson and Dugan (1964) and modified by Raharjo, Sofos and Schmidt (1992) Jô and Ahn (1998). The results were expressed as mg malonaldehyde (MDA). $\mathrm{kg}^{-1}$ products.

\subsection{Statistical analysis}

The experimental data were obtained from analysis in triplicate and were analyzed using the Statistica 6.0 and the Tukey test to compare the means and identify the differences at a significance level of $5 \%$.

\subsection{Sensory analysis}

The sensory analysis was performed with the aid of consumers (panelists) using the acceptance test of "Focus group" (FARIA, 2008). Samples of the four treatments were compared for the evaluation of flavor, odor, color, and brightness.

\section{Results and discussion}

Chemical composition data (Table 1) showed variations among the batches of salami produced with essential oil of Coriandrum sativum L. and BHT. The salamis added with coriander oil had higher values of fat but lower values of protein and moisture. The analyses of protein, moisture, fat, water activity, and nitrite in the salami with coriander oil met the Technical RTQI standards for Italian salami (BRASIL, 2000), as shown in Table 1 . The Aw and acidity values did not showed statistically significant difference of $5 \%$.

The $\mathrm{pH}$ values (Figure 1) showed a decrease on day seven, and the salami with coriander oil had lower values of $\mathrm{pH}$ in this period; this result can be due to the production of lactic acid bacteria. 
Table 1. Chemical compositon of Treatments T1 (Control), T2 (0.01\% of coriander), T3 (0.01\% of BHT), and T4 ( $0.005 \%$ of coriander $+0.005 \%$ de BHT), Tukey test $(\mathrm{p}<0.05)$.

\begin{tabular}{|c|c|c|c|c|c|}
\hline & Moisture \% & Protein \% & Fat $\%$ & Aw & Nitrite mg.kg-1 \\
\hline \multirow[t]{2}{*}{$\mathrm{T} 1$} & $31.8^{\mathrm{a}}$ & $43.5^{\mathrm{a}}$ & $17.45^{\mathrm{a}}$ & $0.85^{\mathrm{a}}$ & $25.08^{\mathrm{a}}$ \\
\hline & $( \pm 0.100)$ & $( \pm 0.100)$ & $( \pm 0.010)$ & $( \pm 0.001)$ & $( \pm 0.010)$ \\
\hline \multirow[t]{2}{*}{$\mathrm{T} 2$} & $32.1^{\mathrm{b}}$ & $43.0^{\mathrm{b}}$ & $17.97^{\mathrm{b}}$ & $0.85^{\mathrm{a}}$ & $25.17^{\mathrm{b}}$ \\
\hline & $( \pm 0.152)$ & $( \pm 0.100)$ & $( \pm 0.010)$ & $( \pm 0.001)$ & $( \pm 0.010)$ \\
\hline \multirow[t]{2}{*}{$\mathrm{T} 3$} & $32.3^{\mathrm{b}}$ & $43.8^{\mathrm{a}}$ & $17.61^{c}$ & $0.86^{\mathrm{a}}$ & $25.10^{c}$ \\
\hline & $( \pm 0.100)$ & $( \pm 0.100)$ & $( \pm 0.010)$ & $( \pm 0.001)$ & $( \pm 0.100)$ \\
\hline \multirow[t]{2}{*}{$\mathrm{T} 4$} & $32.2^{\mathrm{b}}$ & $42.5^{c}$ & $17.61^{\mathrm{c}}$ & $0.85^{\mathrm{a}}$ & $25.05^{\mathrm{d}}$ \\
\hline & $( \pm 0.100)$ & $( \pm 0.152)$ & $( \pm 0.010)$ & $( \pm 0.001)$ & $( \pm 0.010)$ \\
\hline (BRASIL, 2000) & $\max .35 \%$ & $\min .25 \%$ & $\max .32 \%$ & $\max .0 .90$ & $\max .150 \mathrm{ppm}$ \\
\hline
\end{tabular}

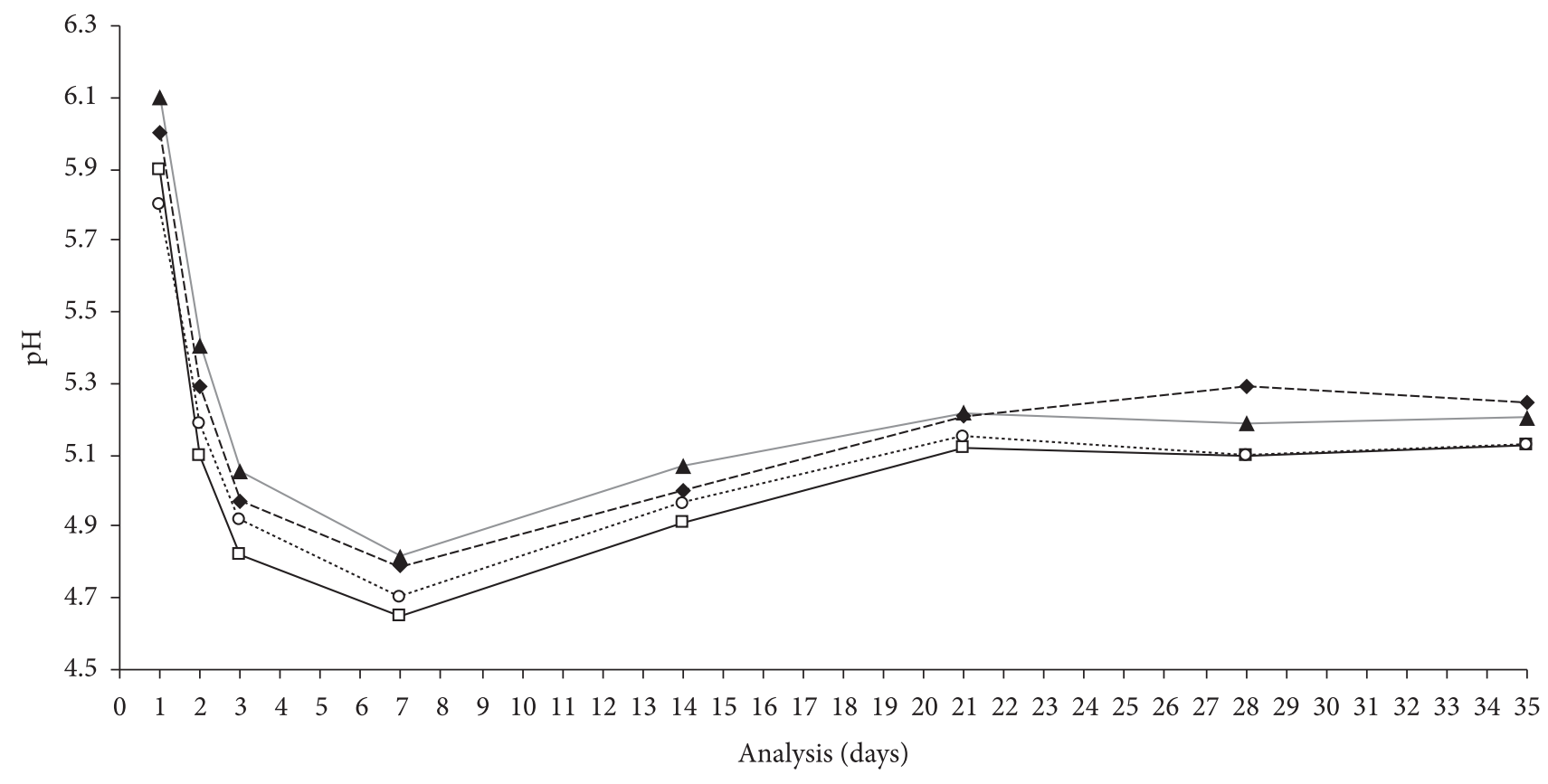

$\leftarrow$ T1 - Control $\neg-$ T2 - Coriander $\quad-\bullet$ T3 - BHT $\quad-$-o- T4 - Coriander + BHT

Figure 1. Change in $\mathrm{pH}$ values during the storage of experimental Italian salamis prepared as follows: without antioxidant (T1), with coriander essential oil (0.01\%) (T2), with BHT (0.01\%) (T3), and with coriander essential oil (0.005\%) and BHT (0.005\%) (T4).

Between the $7^{\text {th }}$ and $21^{\text {th }}$ days, the $\mathrm{pH}$ values had an increase. Such reactions occur because of the decarboxylation and deamination of the amino acids that release ammonia.

This result is similar to that obtained by Scheid (2001) with clove (Eugenia caryophyllus) in salami.

The influence of coriander essential oil in the salamis on the peroxide values is shown in Figure 2. Daily, the highest peroxide values were observed for the salami without antioxidant (T1) followed by T3 (BHT) and T4 (coriander oil and BHT), respectively. A regular increase in peroxide values as a function of storage time was observed for all samples and at all intervals. Initially, the difference in the content of peroxide in the Treatment without antioxidant (T1) T3 (BHT) and T4 (oil coriander and BHT) were not noted.
It became significant only after 14 days. The Treatment T2 (coriander oil) showed significance difference from $\mathrm{T} 1$ on day one. The salami with coriander essential oil remained stable during the entire period of storage maintaining the peroxide value; revealing good antioxidant activity. Caccioppoli et al. (2006) found 0,03986 (mEq.g $\left.{ }^{-1}\right)$ in an Italian salami with a period of validity of 68 days and $0,33482\left(\mathrm{mEq} \cdot \mathrm{kg}^{-1}\right)$ in a product with a period of validity of 118 days.

The salamis treated with the coriander essential oil showed significant difference $(\mathrm{p}<0.05)$ of TBARS values compared to those of the products without antioxidant (T1).

These data indicated lipid oxidation control (antioxidant activity) by the coriander essential oil (Table 2). All TBARS values with antioxidant (T2, T3, and T4), were moderated indicating a low lipid oxidation, wich could not induce a rancid 
Table 2. TBARS values (mg MDA. $\left.\mathrm{kg}^{-1}\right)$ for Treatments T1 (Control), T2 (0.01\% of coriander), T3 (0.01\% of BHT), and T4 (0.005\% of coriander $+0.005 \%$ of $\mathrm{BHT})$.

\begin{tabular}{|c|c|c|c|c|c|c|c|c|c|}
\hline \multicolumn{10}{|c|}{ Time (days) } \\
\hline Treatment & 1 & 7 & 14 & 21 & 28 & 35 & 42 & 63 & 91 \\
\hline \multirow[t]{2}{*}{$\mathrm{T} 1$} & $0.5231^{\mathrm{d}}$ & $0.3871^{\mathrm{d}}$ & $0.5852^{c}$ & $0.8877^{\mathrm{d}}$ & $1,3915^{d}$ & $1.413^{\mathrm{d}}$ & $1.573^{\mathrm{d}}$ & $1.605^{\mathrm{d}}$ & $1.675^{\mathrm{d}}$ \\
\hline & $( \pm 0.000)$ & $( \pm 0, .000)$ & $( \pm 0.000)$ & $( \pm 0.000)$ & $( \pm 0.000)$ & $( \pm 0.001)$ & $( \pm 0.000)$ & $( \pm 0.001)$ & $( \pm 0.000)$ \\
\hline $\mathrm{T} 2$ & $( \pm 0.000)$ & $( \pm 0.000)$ & $( \pm 0.000)$ & $( \pm 0,000)$ & $( \pm 0,000)$ & $( \pm 0.000)$ & $( \pm 0.000)$ & $( \pm 0.000)$ & $( \pm 0,000)$ \\
\hline $\mathrm{T} 3$ & $0.1998^{c}$ & $0.1679^{c}$ & $0.1779^{\mathrm{b}}$ & $0,3942^{c}$ & $1.0499^{\mathrm{b}}$ & $1.0631^{\mathrm{b}}$ & $1,186^{c}$ & $1.198^{\mathrm{c}}$ & $1.172^{\mathrm{c}}$ \\
\hline $\mathrm{T} 4$ & $( \pm 0.001)$ & $( \pm 0.000)$ & $( \pm 0.001)$ & $( \pm 0.000)$ & $( \pm 0.000)$ & $( \pm 0.000)$ & $( \pm 0.001)$ & $( \pm 0.001)$ & $( \pm 0.000)$ \\
\hline
\end{tabular}

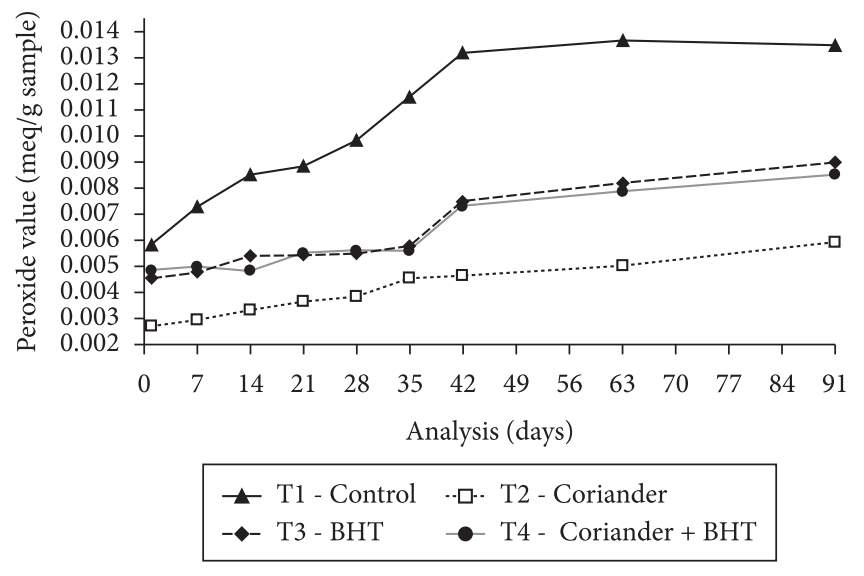

Figure 2. Peroxide value (mEq.g ${ }^{-1}$ sample) in Italian salami prepared as follows: without antioxidant (T1), coriander essential oil $(0.01 \%)$ (T2), BHT (0.01\%) (T3), and coriander essential oil (0.005\%) and BHT $(0.005 \%)$ (T4).

taste (HOZ et al., 2004). Zanardi et al. (2002) found very similar TBARS values also close to 1 (mg MDA.kg-1) after 60 days of vacuum storage.

The sample without antioxidant (T1) showed higher TBARS values after 28 days (mg MDA. $\mathrm{kg}^{-1}$ ) inducing a rancid taste. The TBARS value found for the salami with coriander oil at day $90\left(\mathrm{mg} \mathrm{MDA} \mathrm{kg}^{-1}\right)$ indicated an increase in the shelf life of the product.

The sample with coriander essential oil showed a significant difference for the value of TBARS compared to the sample of salami with BHT T4. It showed better performance than T1 and $\mathrm{T} 3$ but worse performance than T2, according to the Tukey test $(\mathrm{p}<0,05)$.

The sensory evaluation after 90 days indicated that $\mathrm{T} 2$ had the lowest concentrations of flavor and rancid odor demonstrating that the coriander delayed the perception of flavors; therefore, it is as a more effective antioxidant than BHT. The brightness and the red color were improved in T2 compared to the other treatments. The taste and odor of coriander were not perceived by the tasters in the salamis that were enriched with coriander essential oil. T2 increased the shelf life of Italian salami in 30 days compared to T1.

The peroxide value of salami $0.013\left(\mathrm{mEq} \cdot \mathrm{g}^{-1}\right)$ and the TBA value of 1.675 (mg MDA. $\left.\mathrm{kg}^{-1}\right)$ indicated stale taste and smell in the Italian salami type.

\section{Conclusions}

Through the results obtained by the use of coriander essential oil in Italian salami type, it was concluded that:

The Italian salami that received the addition of additives, coriander essential oil or BHT, reduced their levels of peroxides and TBARS index confirming the retardation of lipid oxidation compared to the control salami.

The use of coriander essential oil presented stronger synthetic antioxidant effect than that of BHT (butyl hydroxytoluene) on the retardation of lipid oxidation.

The reduction of BHT in salamis can be achieved with the use of coriander essential oil. The Treatments T3 (BHT) and T4 (coriander + BHT) showed no significant difference in the retardation of lipid oxidation.

\section{References}

AMAROWICZ, R. et al. Antioxidant activity of ethanolic extract of mustard seed. Food Nahrung, v. 40, n. 5, p. 261-268, 1996.

ANILAKUMAR, K. R.; NAGARAJ, N. S.; SANTHANAM, K. Effect of coriander seeds on hexachlorocyclohexane induced lipid peroxidation in rat liver. Nutrition Research, v. 21, p. 1455-1462, 2001.

ARAÚJO, J. M.; MÍDIO, A. F. Determinação espectrofotométrica de nitritos e nitratos após redução com coluna de cádmio/cobre em alimentos destinados à população infantil. Revista de Farmácia e Bioquímica da Universidade de São Paulo, v. 25, n. 1, p. 53-70, 1989.

ASSOCIATION OF OFFICIL ANALYTICAL CHEMIST - AOAC. Official methods of analysis. $16^{\text {th }} \mathrm{ed}$. Washington, DC: Association of Officil Analytical Chemist, 1995.

BRASIL. Instrução Normativa n. 22, de 31 de julho de 2000. Regulamento técnico de identidade e qualidade do salame tipo italiano. Diário Oficial da República Federativa do Brasil, Brasília, DF, 3 ago. 2000. Seção 1, n. 149, p. 24-25. 
CACCIOPPOLI, J. et al. Aminas bioativas e características físicoquímicas de salames tipo italiano. Arquivo Brasileiro de Medicina Veterinária e Zootecnia, v. 58, n. 4, p. 648-657, 2006.

CHIPAULT, J. R. et al. The antioxidant properties of natural spices. Food Research, v. 17, p. 46-55, 1952.

DELAQUIS, P. J. et al. Antimicrobial activity of individual and mixed fractions of dill, cilantro, coriander and eucalyptus essential oils. International Journal of Food Microbiology, v. 74, p. 101-109, 2002.

ESTEVEZ, M. et al. Sage and rosemary essential oils versus BHT for the inhibition of lipid oxidative reaction in liver patê. LWT - Food Science and Technology, v. 40, p. 58-65, 2007.

FARIA, E. V. Técnica de análise sensorial. Campinas: Instituto de Tecnologia de Alimentos - Ital, 2008.

GALVÃO, E. L. et al. Avaliação do potencial antioxidante e extração subcrítica do óleo de linhaça. Ciência e Tecnologia de Alimentos, v. 28 , n. 3, p. 551-557, 2008.

GRAY, J. I.; GOMMA, E. A.; BUCKLEY, D. L. Oxidative quality and shelf life of meats. Meat Science, v. 43, p. 111-123, 1996.

GUARDIOLA, F. et al. Biological effects of oxysterol: current status. Food Chemistry and Toxicology, v. 34, p. 193-211, 1996.

HASHIM, M. S. et al. Effect of polyphenolic compounds from Coriandrum sativum $\mathrm{L}$. on $\mathrm{H}_{2} \mathrm{O}_{2}$-induced oxidative stress in human lymphocytes. Food Chemistry, v. 92, p. 653-660, 2005.

HOZ, L. et al. Development of and n-3 fatty acid and $\alpha$-tocopherol enriched dry fermented sausage. Meat Science, v. 67, p. 485-495, 2004.

JÔ, C.; AHN, D. U. Fluorometric analysis of 2-Thiobarbituric Acid Reactive Substances in Turkey. Poultry Science, v. 77, p. 475-480, 1998.

KAHL, R.; KAPPUS, H. Toxikologie der synthetischen antioxidantien BHA und BHT Vergleich mit dem naturlichen antioxidans vitamin E. Z. Lebensmittelunter u-Forsch, v. 196, p. 329-338, 1993.

KIKUZAKI, H.; NAKATANI, N. Structure of a new antioxidative phenolic acid from oregano (Origanum vulgare L.). Agricultural and Biological Chemistry, v. 53, p. 519-522, 1989.

BRASIL. Ministério da Agricultura. Secretaria Nacional de Defesa Agropecuária. Laboratório Nacional de Referência Animal - LANARA. Métodos analíticos oficiais para controle de produtos de origem animal e seus ingredientes. I - Métodos microbiológicos. II - Métodos físico químicos. Brasília: Ministério da Agricultura, 1981.

LEE, Y.; HOWARD, L. R.; VILLALÓN, B. Flavonoids and antioxidant activity of fresh pepper (Capsicum annuum) cultivars. Journal of Food Science, v. 60, n. 3, p. 473-476, 1995.

LUZIA, D. M. M.; JORGE, N. Atividade antioxidante do extrato de sementes de limão (Citrus limon) adicionado ao óleo de soja em teste de estocagem acelerada. Quimica Nova, v. 32, n. 4, p. 946-949, 2009.
MANCINI FILHO, J. et al. Antioxidant activity of cinnamon (Cinnamomun zeylanicum, Breyne) extracts. Bollettino chimico farmaceutico, v. 137, p. 443-447, 1998.

MARIUTTI, L. R. B.; BRAGAGNOLO, N. Revisão: antioxidantes naturais da família lamiaceae. Aplicação em Produtos Alimentícios. Brazilian Journal of Food Technology, v. 10, n. 2, p. 96-103, 2007.

ÖZCAN, M.; AKGÜL, A. Antioxidant activity of extracts and essential oils from Turkish spices on sunflower oil. Acta-Alimentaria, v. 24, n. 1, p. 81-90, 1995.

QUAST, L. B.; AQUINO, A. D. Oxidação dos lipídeos em café arábica (Coffea Arabica L.) e café Robusta (Coffea canephora P.). Boletim do CEPPA, v. 22, n. 2, p. 325-336, 2004.

RAHARJO, S.; SOFOS, J. N.; SCHMIDT, G. R. Improved speed, specificity, and limit of determination of an aqueous acid extraction thiobarbituric acid- $\mathrm{C}_{18}$ method for measuring lipid peroxidation in beef. Journal of Agricultural and Food Chemistry, v. 40, n. 11, p. 2182-2185, 1992.

ROTA, E. M. et al. Estudo da atividade antioxidante das ervas alecrim, coentro, manjericão, orégano e sálvia. In: ENCONTRO DE QUÍMICA DA REGIÃO SUL - 16-SBQSUL, 16., FURB, 2008. Anais..

SCHEID, G. A. Physical-chemical and sensory evaluation of Italian-type salami at different concentrations of clove (Eugenia caryophyllus). 2001. 93 f. Tese (Doutorado em Ciência e Tecnologia de Alimentos)-Universidade Federal de Viçosa, Viçosa, 2001.

SEMWAL, A. D.; ARYA, S. S. Effect of spices and salt on the storage stability of precooked dehydrated rice. Journal of Food Science and Technology, v. 29, n. 4, p. 210-213, 1992.

SILVA, F. A. M.; BORGES, M. F. M.; FERREIRA, M. A. Métodos para avaliação do grau de oxidação lipídica e da capacidade antioxidante. Química Nova, v. 22, n.1, 1999.

TAKEMOTO, E.; TEIXEIRA FILHO, J.; GODOY, H. D. Validação de metodologia para determinação simultânea dos antioxidantes sintéticos em óleos vegetais, margarinas e gorduras hidrogenadas por CLAE/UV. Química Nova, v. 32, n. 5, p. 1189-1194, 2009.

TANABE, H.; YOSHIDA, M.; TOMITA, N. Comparasion of the antioxidant activities of 22 commonly used herbs and spices on the lipid oxidation of pork meat. Animal Science Journal, v. 73, p. 389-393, 2002.

TARLADGIS, B. G.; PEARSON, A. M.; DUGAN, J. L. R. Chemistry of the 2-thiobarbituric acid test for determination of oxidative rancity in foods. Journal Science Food Agricultury, v. 15, n. 9, p. $602-607,1964$.

VEKIARI, S. A. et al. Oregano flavonoids as lipid antioxidants. Journal of the American Oil Chemists' Society, v. 70, n. 5, p. 483-487, 1993.

WANGENSTEEN, H.; SAMUELSEN, A. B.; MALTERUD, K. E. Antioxidan activity in extract from coriander. Food Chemistry, v. 88, p. 293-297, 2004.

ZANARDI, E. et al. Lipid and colour stability of Milano-type sausage: effects of packing conditions. Meat Science, v. 61, p. 7-14, 2002. 